\title{
Stimulation of 1,25-Dihydroxyvitamin D Production by Parathyroid Hormone and Dibutyryl 3',5'-Cyclic AMP in Normal Subjects, Hypoparathyroidism and Pseudohypoparathyroidism
}

\author{
Hiroshi Unakami, Yohtaro Furukawa, Hyo Euy Sohn, \\ Sigeru Yumita, Ryo Miura, Kunihiko Hanew and \\ KaORU Yoshinaga
}

The Second Department of Internal Medicine, Tohoku University School of Medicine, Sendai 980

\begin{abstract}
Unakami, H., Furukawa, Y., Sohn, H.E., Yumita, S., Miura, R., Hanew, K. and Yoshinaga, K. Stimulation of 1,25-Dihydroxyvitamin D Production by Parathyroid Hormone and Dibutyryl 3',5'-Cyclic AMP in Normal Subjects, Hypoparathyroidism and Pseudohypoparathyroidism. Tohoku J. exp. Med., 1982, 138 (2), 167-175 Parathyroid extract (PTE) or synthetic 1-34 human parathyroid hormone (1-34 hPTH) was injected intravenously as a bolus in 4 normal subjects, 4 patients with PTH deficient hypoparathyroidism (HP) and 3 patients with pseudohypoparathyroidism (PHP). In normal subjects and HP, plasma $1,25(\mathrm{OH})_{2} \mathrm{D}$ was markedly increased at $6 \mathrm{hr}$ and reached the peak at 12 or $14 \mathrm{hr}$ after administration of 200 units of PTE or 20 to $30 \mu \mathrm{g}$ of $1-34 \mathrm{hPTH}$. On the other hand, 500 units of PTE or $20 \mu \mathrm{g}$ of $1-34 \mathrm{hPTH}$ failed to increase plasma $1,25(\mathrm{OH})_{2} \mathrm{D}$ in PHP. However, $2.5 \mathrm{mg} / \mathrm{kg}$ of dibutyryl cAMP remarkably increased plasma $1,25(\mathrm{OH})_{2} \mathrm{D}$ in a patient with PHP. Maximal increments of plasma $1,25(\mathrm{OH})_{2} \mathrm{D}$ in 3 patients with $\mathrm{HP}(21.7 \pm 5.6 \mathrm{pg} / \mathrm{ml}$, mean \pm s.D. $)$ were nearly as high as in normal subjects $(20.6 \pm 7.0 \mathrm{pg} / \mathrm{ml})$, whereas those in 3 patients with PHP $(2.3 \pm 2.3 \mathrm{pg} / \mathrm{ml})$ were distinctly lower than in normal subjects or HP. It is suggested that $1,25(\mathrm{OH})_{2} \mathrm{D}$ production by $\mathrm{PTH}$ is intact in $\mathrm{HP}$, but is impaired in PHP mainly due to a defect in the activation of adenylate cyclase system. - .... parathyroid extract; synthetic 1-34 human parathyroid hormone; dibutyryl 3,'5'-AMP; 1,25-dihydroxyvitamin D; adenylate cyclase system
\end{abstract}

It is generally accepted that the conversion of 25-hydroxyvitamin $\mathrm{D}_{3}$ to 1,25 dihydroxyvitamin $\mathrm{D}_{3}$ in the kidney is enhanced by parathyroid hormone (PTH) (Garabedian et al. 1972; Fraser and Kodicek 1973). In addition, Rasmussen et al. (1972), Larkins et al. (1974) and Horiuchi et al. (1977) reported that $3^{\prime}, 5^{\prime}$-cyclic $\mathrm{AMP}(\mathrm{cAMP})$ or dibutyryl $3^{\prime}, 5^{\prime}$-cyclic $\mathrm{AMP}(\mathrm{DBcAMP})$ reproduced the stimulating effect of PTH on 1,25-dihydroxyvitamin $\mathrm{D}_{3}$ production, suggesting that PTH action is mediated by cAMP.

Therefore, it is plausible that serum concentration of 1,25-dihydroxyvitamin $\mathrm{D}_{3}$ is low due to the lack of PTH in patients with idiopathic or postoperative hypoparathyroidism (HP) (Haussler et al. 1976; Lund et al. 1980; Lambert et al.

Received for publication, January 28, 1982. 
1980; Mason et al. 1980), or due to the unresponsiveness of the kidney tissue to the action of PTH in pseudohypoparathyroidism (PHP) (Drezner et al. 1976; Sinha et al. 1977; Lawoyin et al. 1979; Lambert et al. 1980).

In this study, we examined the responsiveness of vitamin D metabolites to PTH administration in normal subjects, HP and PHP. Additionally, we studied the effect of DBcAMP on the production of vitamin D metabolites in order to demonstrate the impaired cAMP system in a patient with PHP.

\section{Materials and Methods}

Four normal subjects (all were males, aged 24 years), 4 patients with HP (2 males and 2 females, aged 39-70 years) and 3 patients with PHP ( 2 males and 1 female, aged 13-39 years) were studied. Diagnosis of HP or PHP were made according to the amounts of increments in urinary excretion of $\mathrm{P}(\Delta \mathrm{UP})$ and cAMP $(\Delta \mathrm{cAMP})$ after the intravenous injection of 200 units of PTE (Parathormone, Lilly Co., Ltd.) or $20 \mu \mathrm{g}$ of 1-34hPTH (synthetic human parathyroid hormone, Toyo Jozo Co.,Ltd.) (HP: $\Delta \mathrm{UP}>35 \mathrm{mg} / 2 \mathrm{hr}, \Delta \mathrm{Uc}$ AMP $>1.0 \mu$ mole $/ \mathrm{hr}$. PHP: $\Delta \mathrm{UP}<35 \mathrm{mg} / 2 \mathrm{hr}, \quad \Delta \mathrm{UcAMP}<1.0 \mu \mathrm{mole} / \mathrm{hr}) . \quad \mathrm{By}$ these criteria Cases 5, 6, 7 and 8 were diagnosed as HP, while Cases 9, 10 and 11 were as PHP (Table 1).

TABLE 1. Summary of the experimental subjects

\begin{tabular}{|c|c|c|c|c|c|c|c|c|}
\hline \multirow[b]{2}{*}{$\begin{array}{c}\text { Subject } \\
\text { No. }\end{array}$} & \multirow[b]{2}{*}{ Diagnosis } & \multirow[b]{2}{*}{ Sex/Age } & \multicolumn{2}{|l|}{ Serum } & \multirow[b]{2}{*}{$\begin{array}{c}\mathrm{iPTH}^{*} \\
(\mathrm{ng} / \mathrm{ml})\end{array}$} & \multicolumn{2}{|c|}{ Plasma } & \multirow[b]{2}{*}{$\begin{array}{c}1,25 \\
(\mathrm{OH})_{2} \mathrm{D} \\
(\mathrm{pg} / \mathrm{ml})\end{array}$} \\
\hline & & & $\begin{array}{l}\mathrm{Ca} \\
(\mathrm{mg} / 100 \mathrm{~m}\end{array}$ & & & $\begin{array}{r}250 \mathrm{HD} \\
(\mathrm{ng} / \mathrm{ml})\end{array}$ & $\begin{array}{c}24,25 \\
(\mathrm{OH})_{2} \mathrm{D} \\
(\mathrm{ng} / \mathrm{ml})\end{array}$ & \\
\hline 1 & Normal & $\mathrm{M} / 24$ & 9.4 & 3.2 & $<0.3$ & 10.9 & 1.47 & 46.6 \\
\hline 2 & Normal & $\mathrm{M} / 24$ & 9.3 & 2.7 & $<0.3$ & 8.7 & 2.13 & 51.5 \\
\hline 3 & Normal & $\mathrm{M} / 24$ & 9.7 & 3.0 & $<0.3$ & 11.1 & 2.42 & 29.9 \\
\hline 4 & Normal & $\mathrm{M} / 24$ & 9.4 & 3.2 & $<0.3$ & 20.0 & 2.24 & 25.3 \\
\hline 5 & HP & $\mathrm{F} / 70$ & 5.8 & 5.9 & $<0.3$ & 17.2 & 1.45 & $<5.0$ \\
\hline 6 & $\mathrm{HP}$ & $\mathrm{F} / 45$ & 5.9 & 5.7 & $<0.3$ & 17.2 & 1.57 & $<5.0$ \\
\hline 7 & $\mathrm{HP}$ & $\mathrm{M} / 50$ & 4.9 & 6.6 & $<0.3$ & 8.0 & 1.95 & 21.2 \\
\hline 8 & $\mathrm{HP}$ & $\mathrm{M} / 39$ & 6.2 & 4.2 & $<0.3$ & 9.6 & 2.77 & 33.7 \\
\hline 9 & PHP & $\mathrm{M} / 24$ & 7.7 & 3.9 & 0.60 & 6.8 & 1.15 & 10.3 \\
\hline 10 & $\mathrm{PHP}$ & $\mathrm{M} / 13$ & 7.3 & 5.4 & 0.72 & $\begin{array}{r}0.0 \\
10.9\end{array}$ & 1.17 & 41.6 \\
\hline 11 & PHP & $\mathrm{F} / 39$ & 7.7 & 4.9 & 0.46 & 8.8 & 1.42 & 32.3 \\
\hline
\end{tabular}

* Normal range was less than $0.4 \mathrm{ng} / \mathrm{ml}$.

After an overnight fast, 200 units of PTE were intravenously injected over $10 \mathrm{~min}$ to 3 patients with HP (Cases 5, 6, 7) and 500 units of PTE were intravenously infused with $250 \mathrm{ml}$ of normal saline for $1 \mathrm{hr}$ to 2 patients with PHP (Cases 9, 10) to evaluate the responsiveness of vitamin D metabolites to PTH. Similarly, $30 \mu \mathrm{g}$ of 1-34 hPTH were injected to 4 normal subjects, and $20 \mu \mathrm{g}$ of $1-34 \mathrm{hPTH}$ to a patient with HP (Case 8 ) and a patient with PHP (Case 11), respectively. In addition, $2.5 \mathrm{mg} / \mathrm{kg}$ of DBcAMP was intravenously infused with $250 \mathrm{ml}$ of normal saline for $1 \mathrm{hr}$ to a patient with PHP (Case 9). Blood was drawn before and 3, 6, 12 (14), and $24 \mathrm{hr}$ after the administration of PTH or DBcAMP for the determination of serum calcium (Ca), phosphate $(\mathrm{P})$ and plasma vitamin D metabolites. Furthermore, hourly urine in each subject was collected for $3 \mathrm{hr}$ before and after the administration of PTH or DBcAMP to quantitate urinary $\mathbf{P}$ and cAMP.

Serum Ca was measured by EGTA titrimetry, and serum or urinary $\mathrm{P}$ were by Fiske and Subbarow's method (1925). Plasma immunoreactive PTH (iPTH) was quantitated by radioimmunoassay utilizing a PTH assay kit (Eiken Co., Ltd.). Urinary cAMP was 
measured by radioimmunoassay using a cAMP assay kit (Yamasa Shoyu Co., Ltd.) (Honma et al. 1977).

Plasma vitamin D metabolites (25-hydroxyvitamin D [25OHD], 24,25-dihydroxyvitamin $\mathrm{D}\left[24,25(\mathrm{OH})_{2} \mathrm{D}\right]$ and 1,25-dihydroxyvitamin $\mathrm{D}\left[1,25(\mathrm{OH})_{2} \mathrm{D}\right]$ were quantitated as follows: 3 to $5 \mathrm{ml}$ of blood plasma were extracted with methylene chloride after addition of 6000 $\mathrm{dpm}$ of $\left[23,24(\mathrm{n})-{ }^{3} \mathrm{H}\right]-250 \mathrm{OD}_{3}(70-110 \mathrm{Ci} / \mathrm{mmole}), 6000 \mathrm{dpm}$ of $\left[23,24(\mathrm{n}){ }^{-3} \mathrm{H}\right]-24 \mathrm{R}, 25(\mathrm{OH})_{2} \mathrm{D}_{3}$ $(50-80 \mathrm{Ci} / \mathrm{mmole})$ and $6000 \mathrm{dpm}$ of $\left[23,24(\mathrm{n}){ }^{-3} \mathrm{H}\right]-1 \alpha, 25(\mathrm{OH})_{2} \mathrm{D}_{3}(70-110 \mathrm{Ci} / \mathrm{mmole})$ (Amersham) for evaluating the recovery rates. The extracts were applied to the Sephadex LH-20 column $(0.7 \times 14 \mathrm{~cm})$ with a mixed solvent of chloroform and hexane $(60: 40, \mathrm{v} / \mathrm{v})$ as described by Kano et al. (1979). $250 \mathrm{HD}$ fraction $(4-10 \mathrm{ml}), 24,25(\mathrm{OH})_{2} \mathrm{D}$ fraction $(10-20$ $\mathrm{ml}$ ) and $1,25(\mathrm{OH})_{2} \mathrm{D}$ fraction $(20-40 \mathrm{ml})$ were separately collected. Then, both $24,25(\mathrm{OH})_{2} \mathrm{D}$ and $1,25(\mathrm{OH})_{2} \mathrm{D}$ fractions were applied to high pressure liquid chromatography (Yanagimoto, L-2000. $\mu$ porasil silicic acid column, $\phi 4 \times 250 \mathrm{~mm}$ ) with a mixed solvent of $3 \%$ methanol in methylene chloride at flow rate of $1.0 \mathrm{ml} / \mathrm{min}$ for further purification. The overall recovery of each metabolite was; $25 \mathrm{OHD} 35.4 \pm 6.1 \%, 24,25(\mathrm{OH})_{2} \mathrm{D}$ $59.6 \pm 11.6 \%, 1,25(\mathrm{OH})_{2} \mathrm{D} 57.3 \pm 9.9 \%$ (mean \pm s.D. $)$. The assays for $25 \mathrm{OHD}$ and $24,25(\mathrm{OH})_{2}$ D were carried out by the method of Belsey et al. (1971) and Talor et al. (1976), respectively. $1,25(\mathrm{OH})_{2} \mathrm{D}$ was quantitated by radioreceptor assay using the intestinal cytosol receptor from vitamin $D$ deficient chickens according to the method of Eisman et al. (1976). The within- and between-assay coefficients of variation for the determination of the metabolites were; $25 \mathrm{OHD} 9.9 \%$ and $17.7 \%, 24,25(\mathrm{OH})_{2} \mathrm{D} 10.4 \%$ and $18.1 \%, 1,25(\mathrm{OH})_{2} \mathrm{D}$ $13.1 \%$ and $18.4 \%$, respectively. Normal ranges of the metabolites in adult volunteers were; $250 H D 20.5 \pm 5.4 \mathrm{ng} / \mathrm{ml}$ ( $n=6$, from April to September) or $16.7 \pm 5.4 \mathrm{ng} / \mathrm{ml}$ ( $n=13$, from October to March), 24,25(OH) ${ }_{2} \mathrm{D} 1.73 \pm 0.62 \mathrm{ng} / \mathrm{ml}(n=17), 1,25(\mathrm{OH})_{2} \mathrm{D}, 37.2 \pm 13.8 \mathrm{pg} / \mathrm{ml}$ $(n=21)$ (mean \pm s.D.).

Student's $t$ test was used for statistical analyses, and the variance of the mean was expressed as S.D.

\section{Results}

In 4 normal subjects, the basal values of serum $\mathrm{Ca}$ and $\mathrm{P}$ were $9.5 \pm 0.2 \mathrm{mg} /$ $100 \mathrm{ml}$ and $3.0 \pm 0.2 \mathrm{mg} / 100 \mathrm{ml}$, and those of plasma vitamin $\mathrm{D}$ metabolites were; $25 \mathrm{OHD} \quad 12.7 \pm 5.0 \mathrm{ng} / \mathrm{ml}, \quad 24,25(\mathrm{OH})_{2} \mathrm{D} \quad 2.07 \pm 0.41 \mathrm{ng} / \mathrm{ml}, \quad 1,25(\mathrm{OH})_{2} \mathrm{D} \quad 38.3 \pm 12.7$ $\mathrm{pg} / \mathrm{ml} .4$ patients with HP showed a low basal serum Ca $(5.7 \pm 0.6 \mathrm{mg} / 100 \mathrm{ml})$ and a high basal serum $\mathrm{P}(5.6 \pm 1.0 \mathrm{mg} / 100 \mathrm{ml})$. The basal value of plasma $250 \mathrm{HD}$ was $13.0 \pm 4.9 \mathrm{ng} / \mathrm{ml}$ and that of plasma $24,25(\mathrm{OH})_{2} \mathrm{D}$ was $1.94 \pm 0.60 \mathrm{ng} / \mathrm{ml}$. In 2 of these patients, plasma $1,25(\mathrm{OH})_{2} \mathrm{D}$ were less than $5.0 \mathrm{pg} / \mathrm{ml}$, but were within normal range in the remaining 2 patients (Cases 7,8). In 3 patients with $\mathrm{PHP}$, the basal values of serum $\mathrm{Ca}$, serum $\mathrm{P}$, plasma $25 \mathrm{OHD}$ and plasma $24,25(\mathrm{OH})_{2} \mathrm{D}$ were $7.6 \pm 0.2 \mathrm{mg} / 100 \mathrm{ml}, \quad 4.7 \pm 0.8 \mathrm{mg} / 100 \mathrm{ml}, \quad 8.8 \pm 2.1 \mathrm{ng} / \mathrm{ml}$ and $1.25 \pm 0.15 \mathrm{ng} / \mathrm{ml}$, respectively. The basal value of plasma $1,25(\mathrm{OH})_{2} \mathrm{D}$ was lower than normal in a patient, but within normal range in the other 2 patients (Cases 10, 11) (Table 1).

After the administration of 200 units of PTE, plasma $1,25(\mathrm{OH})_{2} \mathrm{D}$ was markedly increased at $6 \mathrm{hr}$, reached its peak at $14 \mathrm{hr}$ and remained plateau or slightly decreased at $24 \mathrm{hr}$ in 3 patients with $\mathrm{HP}$ (Cases 5, 6, 7). In contrast, 500 units of PTE failed to increase plasma $1,25(\mathrm{OH})_{2} \mathrm{D}$ in 2 patients with $\mathrm{PHP}$ (Cases $9,10)$ (Fig. 1). Plasma $24,25(\mathrm{OH})_{2} \mathrm{D}$ was distinctly decreased in patient with $\mathrm{HP}$ (Case 6), but showed no significant changes in another patient with $\mathrm{HP}$ and 2 patients with PHP. After the administration of 1-34 hPTH, plasma $1,25(\mathrm{OH})_{2} \mathrm{D}$ was increased, as was seen by PTE, in 4 normal subjects and a patient with HP 


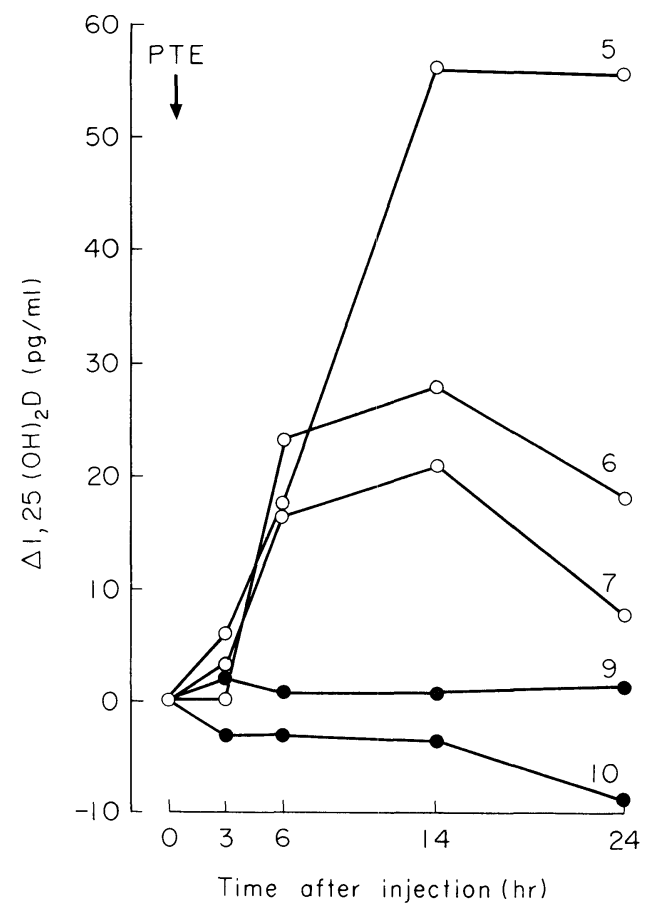

Fig. 1. Effect of PTE on plasma $1,25(\mathrm{OH})_{2} \mathrm{D}$ production in patients with $\mathrm{HP}(\mathrm{O}-\mathrm{O}$ Cases 5, 6, 7) and PHP (- Cases 9, 10). Marked increments in plasma $1,25(\mathrm{OH})_{2} \mathrm{D}$ were seen only in HP.

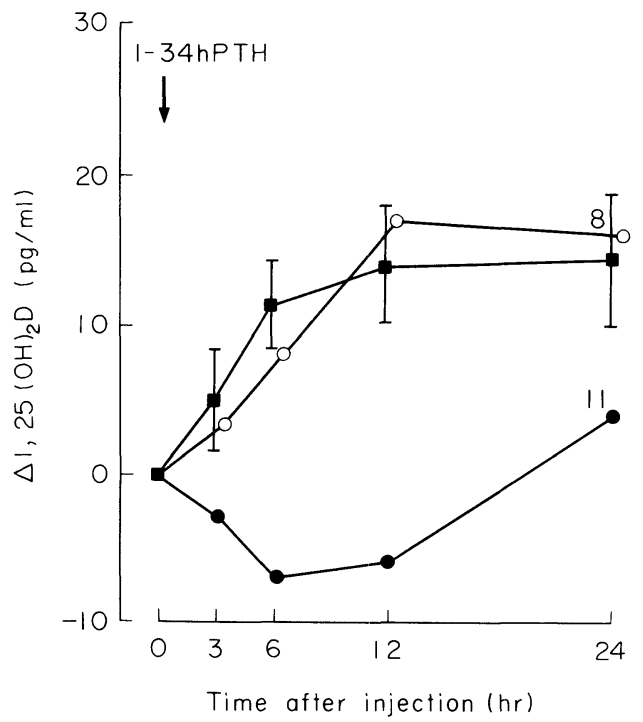

Fig. 2. Effect of 1-34hPTH on plasma $1,25(\mathrm{OH})_{2} \mathrm{D}$ production in normal subjects (- $n=4$, mean \pm S.D. $)$, a patient with HP (०11). Increments in plasma $1,25(\mathrm{OH})_{2} \mathrm{D}$ were seen in normal subjects and $\mathrm{HP}$, but not in PHP. 
(Case 8), but no increment was seen in a patient with PHP (Case 11) (Fig. 2). Plasma $24,25(\mathrm{OH})_{2} \mathrm{D}$ was decreased in a patient with $\mathrm{HP}$, whereas no significant changes were seen in 4 normal subjects or a patient with PHP.

There were no significant changes in serum $\mathrm{Ca}, \mathrm{P}$ or plasma $25 \mathrm{OHD}$ in any subjects with PTE or 1-34hPTH.

TABLE 2. Changes in urinary $P$, urinary cAMP and plasma $1,25(\mathrm{OH})_{2} \mathrm{D}$ by $\mathrm{PTH}$ administration

\begin{tabular}{|c|c|c|c|c|}
\hline $\begin{array}{c}\text { Subject } \\
\text { No. }\end{array}$ & $\begin{array}{c}\text { Administered } \\
\text { PTH }\end{array}$ & $\begin{array}{l}\Delta \text { Urinary P } \\
(\mathrm{mg} / 2 \mathrm{hr})\end{array}$ & $\begin{array}{l}\Delta \text { Urinary cAMP } \\
(\mu \text { moles } / \mathrm{hr})\end{array}$ & $\begin{array}{c}\text { Maximal } \\
\Delta \text { plasma } 1,25(\mathrm{OH})_{2} \mathrm{D} \\
(\mathrm{pg} / \mathrm{ml})\end{array}$ \\
\hline 1 & 1-34hPTH $30 \mu \mathrm{g}$ & - & 14.09 & 25.9 \\
\hline 2 & 1-34hPTH $30 \mu \mathrm{g}$ & - & 12. 26 & 25.7 \\
\hline 3 & 1-34hPTH $30 \mu \mathrm{g}$ & - & 8.22 & 11.0 \\
\hline 4 & 1-34hPTH $30 \mu \mathrm{g}$ & - & 14.26 & 19.6 \\
\hline 5 & Parathormone $200 \mathrm{U}$ & 101.7 & 7.99 & 56.2 \\
\hline 6 & Parathormone $200 \mathrm{U}$ & 44.3 & 9.08 & 27.7 \\
\hline 7 & Parathormone $200 \mathrm{U}$ & 156.2 & 15.29 & 20.8 \\
\hline 8 & 1-34hPTH $20 \mu \mathrm{g}$ & 48.5 & 8.15 & 16.6 \\
\hline 9 & Parathormone 500U & $30.5^{*}$ & 0.21 & 2.3 \\
\hline 10 & Parathormone 500U & $74.9 \dagger$ & 0.24 & 0.2 \\
\hline 11 & 1-34hPTH $20 \mu \mathrm{g}$ & 12.6 & 0.99 & 4.6 \\
\hline
\end{tabular}

* 12.2/200 units of Parathormone.

$\dagger 30.0 / 200$ units of Parathormone.

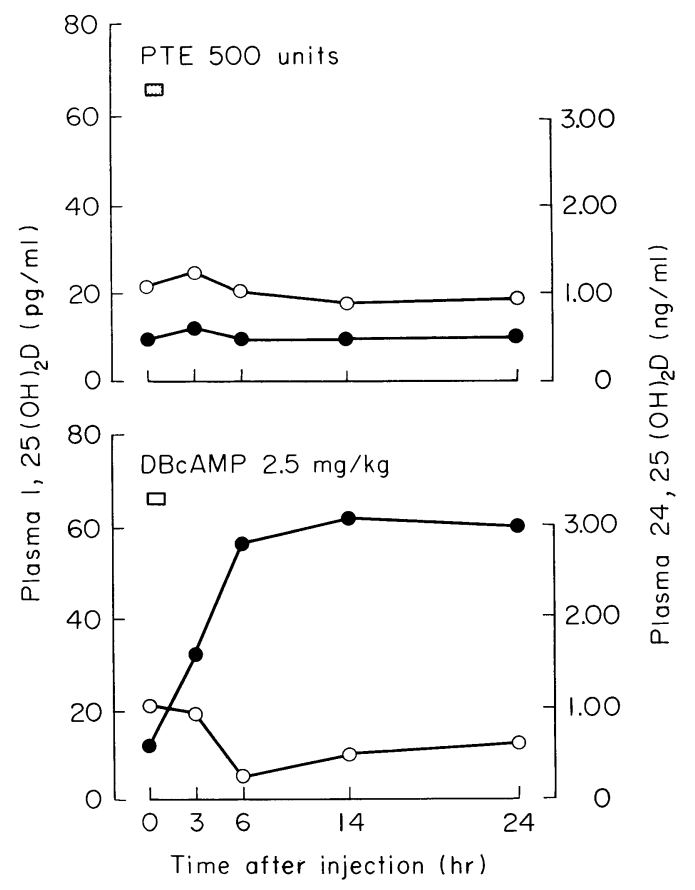

Fig. 3. Effects of PTE (upper) and DBcAMP (lower) on plasma vitamin D metabolites production in a patient with PHP (Case 9). DBcAMP caused a marked increment of plasma $1,25(\mathrm{OH})_{2} \mathrm{D}(\bullet-\bullet)$ and a reciprocal decrement of plasma $24,25(\mathrm{OH})_{2} \mathrm{D}(\mathrm{O}-\mathrm{O})$, though no responses were seen by PTE administration. 
By PTH administration, the urinary excretion of $\mathrm{P}$ increased to more than 35 $\mathrm{mg} / 2 \mathrm{hr}$ in all patients with HP, but less than $35 \mathrm{mg} / 2 \mathrm{hr}(200$ units of PTE or 20 $\mu \mathrm{g}$ of $1-34 \mathrm{hPTH})$ in all patients with PHP. While, increments in the urinary excretion of cAMP in normal subjects and HP were more than $1.0 \mu \mathrm{mole} / \mathrm{hr}$, and less than $1.0 \mu \mathrm{mole} / \mathrm{hr}$ in all patients with PHP. The maximal increment of plasma $1,25(\mathrm{OH})_{2} \mathrm{D}$ in 3 patients with $\mathrm{HP}$ (Cases $6,7,8$,) was $21.7 \pm 5.6 \mathrm{pg} / \mathrm{ml}$, which was as high as in normal subjects $(20.6 \pm 7.0 \mathrm{pg} / \mathrm{ml})$, although a patient with HP (Case 5) showed an extremely high value $(52.6 \mathrm{pg} / \mathrm{ml})$. In 3 patients with PHP, the maximal increment of $1,25(\mathrm{OH})_{2} \mathrm{D}$ was $2.3 \pm 2.3 \mathrm{pg} / \mathrm{ml}$, and it was significantly lower than in normal subjects $(p<0.01)$ or in HP $(p<0.05)$ (Table 2). But there were no significant correlations between the maximal increments of plasma 1,25$(\mathrm{OH})_{2} \mathrm{D}$ and the increments of urinary excretion of $\mathrm{P}$ or those of cAMP in any subjects.

In a patient with PHP (Case 9) who failed to demonstrate any change in plasma vitamin D metabolites to 500 units of PTE, $2.5 \mathrm{mg} / \mathrm{kg}$ of DBcAMP brought about marked increment of plasma $1,25(\mathrm{OH})_{2} \mathrm{D}$ and reciprocal decrement of plasma $24,25(\mathrm{OH})_{2} \mathrm{D}$ (Fig. 3). Besides, urinary excretion of $\mathrm{P}$ was markedly increased $(4 \mathrm{UP}=113.3 \mathrm{mg} / 2 \mathrm{hr}$ ).

\section{Discussion}

As has been reported by other workers (Haussler et al. 1976; Lund et al. 1980; Lambert et al. 1980), plasma $1,25(\mathrm{OH})_{2} \mathrm{D}$ in $\mathrm{HP}$ seems to be low due to the lack of PTH. However, as the $1 \alpha$-hydroxylation system is thought to be intact in this disease, exogenous PTH may be able to stimulate $1 \alpha$-hydroxylase which subsequently increases plasma $1,25(\mathrm{OH})_{2} \mathrm{D}$. Mason et al. (1980) reported that a single injection of PTE (400 units) markedly increased the plasma $1,25(\mathrm{OH})_{2} \mathrm{D}$ level and reached the peak value at $14 \mathrm{hr}$ after the injection in surgical HP. Eisman et al. (1979) also reported that twice injections of $2.5 \mathrm{U} / \mathrm{kg}$ of PTE (up to $200 \mathrm{U}$ ) caused an increment of serum $1,25(\mathrm{OH})_{2} \mathrm{D}$ (peak $8-40 \mathrm{hr}$ ) in healthy volunteers. In our study, a single injection of 200 units of PTE or 20 to $30 \mu \mathrm{g}$ of 1-34 hPTH clearly increased plasma $1,25(\mathrm{OH})_{2} \mathrm{D}$ in either patients of $\mathrm{HP}$ or normal subjects. Peak values of plasma $1,25(\mathrm{OH})_{2} \mathrm{D}$ after injection were obtained at 12 or $14 \mathrm{hr}$ in $\mathrm{HP}$ and at $24 \mathrm{hr}$ in normal subjects, the peak time being nearly the same as those reported previously. Additionally, peak values of plasma $1,25(\mathrm{OH})_{2} \mathrm{D}$ might be similar to those of other reports if injection doses were considered. Some workers proposed the inhibitory effect of PTH on 24-hydroxylase activity from animal or in vitro experiments (Tanaka et al. 1975; Juan and DeLuca 1977), but few workers reported the decrement of plasma $24,25(\mathrm{OH})_{2} \mathrm{D}$ after PTH administration in man. In our patients with $\mathrm{HP}$ and normal subjects, changes in plasma $24,25(\mathrm{OH})_{2} \mathrm{D}$ after injection of PTE or 1-34 hPTH were varying, i.e. plasma $24,25(\mathrm{OH})_{2} \mathrm{D}$ was distinctly decreased only in 2 patients with HP, there being no changes in others. The reason of this difference in responsiveness to PTH is still unknown.

In PHP, as many authors reported, plasma $1,25(\mathrm{OH})_{2} \mathrm{D}$ seems to be low 
depending upon the unresponsiveness to PTH in the kidney tissue (Drezner et al. 1976; Sinha et al. 1977; Metz et al. 1977). Furthermore, other authors reported that stimulating effect of PTH on $1,25(\mathrm{OH})_{2} \mathrm{D}$ production was not seen in this disease (Lambert et al. 1980; Mason et al. 1980) unless PTH was repeatedly administered (Lawoyin et al. 1979). In our study, neither increments of plasma $1,25(\mathrm{OH})_{2} \mathrm{D}$ nor decrements of plasma $24,25(\mathrm{OH})_{2} \mathrm{D}$ were seen in 2 patients injected with PTE or in a patient injected with 1-34hPTH. Even large doses of PTE (500 units) failed to cause any change in vitamin D metabolites in PHP. This lack of changes in plasma vitamin D metabolites was related to the lack of changes in cAMP and $\mathrm{P}$ excretion.

As to the maximal increments of plasma $1,25(\mathrm{OH})_{2} \mathrm{D}$, there was a significant difference between normal subjects and PHP $(\mathrm{P}<0.01)$ or between HP and PHP $(p<0.05)$. Moreover no overlaps were seen in the values of maximal increment of plasma $1,25(\mathrm{OH})_{2} \mathrm{D}$ between normal subjects and PHP or between HP and PHP, though injection doses of PHP were varying. Therefore, it seemed possible to differentiate $\mathrm{HP}$ and $\mathrm{PHP}$ from each other by evaluating the maximal increment of plasma $1,25(\mathrm{OH})_{2} \mathrm{D}$ using the method of a single PTH administration, even though there were overlaps in their basal values of plasma $1,25(\mathrm{OH})_{2} \mathrm{D}$.

In our study, there were no significant correlations between the maximal increments of plasma $1,25(\mathrm{OH})_{2} \mathrm{D}$ and the increments of urinary excretion of $\mathrm{P}$ or those of cAMP in any subjects. But, the responses of $1,25(\mathrm{OH})_{2} \mathrm{D}$ production to PTH might be correlated to the increments of urinary excretion of $\mathrm{P}$ or cAMP if more subjects were studied, as they showed differences between normal subjects and PHP, or between HP and PHP.

The impairment of the adenylate cyclase system in PHP is well known (Chase et al. 1969; Bell et al. 1972). Drezner et al. (1973) classified PHP into 2 types; impairment of an increase in intracellular cAMP (Type I), an inability of intracellular cAMP to initiate the chain of metabolic events (Type II). In our study, $2.5 \mathrm{mg} / \mathrm{kg}$ of DBcAMP remarkably increased plasma $1,25(\mathrm{OH})_{2} \mathrm{D}$ in a patient with $\mathrm{PHP}$ of Type I (Case 9) with a reciprocal decrease in plasma 24,25- $(\mathrm{OH})_{2} \mathrm{D}$. Relating to these findings, some workers demonstrated that cAMP or DBcAMP reproduced the stimulating effect of $\mathrm{PTH}$ on $1,25(\mathrm{OH}) \mathrm{D}_{2}$ production by in vitro or in vivo animal experiments (Rasmussen et al. 1972; Larkins et al. 1974; Horiuchi et al. 1977). Taken together, it is suggested that DBcAMP stimulates $1 \alpha$-hydroxylase activity and inhibits 24-hydroxylase activity in Type I PHP, and that the mechanism of production or inhibition of vitamin D metabolites after cAMP producing system is not impaired.

\section{Acknowledgments}

We wish to thank to Professor Tatsuo Suda, Showa University Dental School for his kind instruction for the measurement of plasma vitamin D metabolites. We also wish to acknowledge with thanks to Chugai Pharm. Co., Ltd., Japan, Rosche Co., Ltd. and Yamasa Shoyu Co., Ltd. for their supply of vitamin D metabolites standards or chicken receptor protein. 


\section{References}

1) Bell, N.H., Avery, S., Sinha, T., Clark, C.M., Jr., Allen, D.O. \& Johnston, C., Jr. (1972) Effects of dibutyryl cyclic adenosine $3^{\prime}, 5^{\prime}$-monophosphate and parathyroid extract on calcium and phosphorus metabolism in hypoparathyroidism and pseudohypoparathyroidism. J. clin. Invest., 51, 816-823.

2) Belsey, R., DeLuca, H.F. \& Potts, J.T., Jr. (1971) Competitive binding assay for vitamin $\mathrm{D}$ and 25-OH vitamin D. J. clin. Endocr. Metab., 33, 554-557.

3) Chase, L.P., Melson, G.L. \& Aurbach, G.D. (1969) Pseudohypoparathyroidism: defective excretion of $3^{\prime}, 5^{\prime}$-AMP in response to parathyroid hormone. J. clin. Invest., 48, 1832-1844.

4) Drezner, M., Neelon, F.A. \& Lebovitz, H.E. (1973) Pseudohypoparathyroidism type II: a possible defect in the reception of the cyclic AMP signal. New Engl. J. Med., 15, 1056-1060.

5) Drezner, M.K., Neelon, F.A., Haussler, M., McPherson, H.T. \& Lebovitz, H.E. (1976) 1,25-Dihydroxycholecalciferol deficiency: the probable cause of hypocalcemia and metabolic bone disease in pseudohypoparathyroidism. J. clin. Endocr. Metab., 42, 621-628.

6) Eisman, J.A., Hamstra, A.J., Kream, B.E. \& DeLuca, H.F. (1976) Sensitive, precise, and convenient method for determination of 1,25-dihydroxyvitamin $\mathrm{D}$ in human plasma. Arch. Biochem. Biophys., 176, 235-243.

7) Eisman, J.A., Wark, J.D., Prince, R.L. \& Moseley, J.M. (1979) Modulation of plasma 1,25-dihydroxyvitamin $\mathrm{D}$ in man by stimulation and suppression tests. Lancet, 2, 931-933.

8) Fiske, C.H. \& Subbarow, Y. (1925) The calorimetric determination of phosphorus. J. biol. Chem., 66, 375-400.

9) Fraser, D.R. \& Kodicek, E. (1973) Regulation of 25-hydroxycholecalciferol-1-hydroxylase activity in kidney by parathyroid hormone. Nature, 241, 163-166.

10) Garabedian, M., Holick, M.F., DeLuca, H.F. \& Boyle, I.T. (1972) Control of 25hydroxycholecalciferol metabolism by parathyroid glands. Proc. nat. Acad. Sci. USA, 69, 1673-1676.

11) Haussler, M.R., Baylink, D.J., Hughes, M.R., Brumbaugh, P.F., Wergedal, J.E., Shen, F.H., Nielsen, R.L., Counts, S.J., Bursac, K.M. \& McCain, T.A. (1976) The assay of $1 a, 25$-dihydroxyvitamin $\mathrm{D}_{3}$ : physiologic and pathologic modulation of circulating hormone levels. Clin. Endocr., 5, 151s-165s.

12) Honma, M., Satoh, T., Takezawa, J. \& Ui, M. (1977) An ultrasensitive method for the simultaneous determination of cyclic AMP and cyclic GMP in small volume samples from blood and tissue. Biochem. Med., 18, 257-273.

13) Horiuchi, N., Suda, T., Takahashi, H., Shimazawa, E. \& Ogata, E. (1977) In vivo evidence for the intermediary role of $3^{\prime}, 5^{\prime}$-cyclic AMP in parathyroid hormone-induced stimulation of 1a,25-dihydroxyvitamin $\mathrm{D}_{3}$ synthesis in rats. Endocrinology, 101, 969974.

14) Juan, D. \& DeLuca, H.F. (1977) The regulation of 24,25-dihydroxyvitamin $D_{3}$ production in cultures of monkey kidney cell. Endocrinology, 101, 1184-1193.

15) Kano, K., Yoshida, H., Yata, J., Abe, E., Tanabe, R. \& Suda, T. (1979) An assay method for separately measuring metabolites of vitamin $D_{3}$ and those presumed to be derived from vitamin $\mathrm{D}_{2}$. J. Nutr. Sci. Vitaminol., 25, 351-360.

16) Lambert, P.W., Hollis, B.W., Bell, N.H. \& Epstein, S. (1980) Demonstration of a lack of change in serum $1 \alpha, 25$-dihydroxyvitamin $\mathrm{D}$ in response to parathyroid extract in pseudohypoparathyroidism. J. clin. Invest., 66, 782-791.

17) Larkins, R.G., MacAuley, S.J., Rapoport, A., Martin, T.J., Tulloch, B.R., Byfield, P.G. H., Matthews, E.W. \& MacIntyre, I. (1974) Effects of nucleotides, hormones, ions and 1,25-dihydroxycholecalciferol on 1,25-dihydroxycholecalciferol production in isolated chick renal tubules. Clin. Sci. mol. Med., 46, 569-582.

18) Lawoyin, S., Norman, D.A., Zerwekh, J.E., Breslau, N.A. \& Pak, C.Y.C. (1979) A patient with pseudohypoparathyroidism with increased serum calcium and $1 a, 25$ - 
dihydroxyvitamin D after exogenous parathyroid hormone administration. $J$. clin. Endocr. Metab., 49, 783-786.

19) Lund, Bj., Sørensen, O.H., Lund, Bi., Bishop, J.E. \& Norman, A.W. (1980) Vitamin D metabolism in hypoparathyroidism. J. clin. Endocr. Metab., 51, 606-610.

20) Mason, R.S., Lissner, D. \& Posen, S. (1980) Parathyroid hormone effect on 1,25dihydroxyvitamin D in hypoparathyroidism. Ann. intern. Med., 92, 260.

21) Metz, S.A., Baylink, D.J., Hughes, M.R., Haussler, M.R. \& Robertson, R.P. (1977) Selective deficiency of 1,25-dihydroxycholecalciferol. A cause of isolated skeletal resistance to parathyroid hormone. New Engl. J. Med., 297, 1084-1090.

22) Rasmussen, H., Wong, M., Bikle, D. \& Goodman, D.B.P. (1972) Hormonal control of the renal conversion of 25-hydroxycholecalciferol to 1,25-dihydroxycholecalciferol. J. clin. Invest., 51, 2502-2504.

23) Sinha, T.K., DeLuca, H.F. \& Bell, N.H. (1977) Evidence for a defect in the formation of $1 \propto, 25$-dihydroxyvitamin $\mathrm{D}$ in pseudohypoparathyroidism. Metabolism, 26, 731-738.

24) Talor, C.M., Hughes, S.E. \& Silva, P. (1976) Competitive protein binding assay for 24,25-dihydroxycholecalciferol. Biochem. biophys. Res. Commun., 70, 1243-1249.

25) Tanaka, Y., Lorenc, R.S. \& DeLuca, H.F. (1975) The role of 1,25-dihydroxyvitamin $\mathrm{D}_{3}$ and parathyroid hormone in the regulation of chick renal 25-hydroxyvitamin $\mathrm{D}_{3^{-}}$ 24-hydroxylase. Arch. Biochem. Biophys., 171, 521-526. 